\title{
Pengaturan dan Urgensi Whistle Blower dan Justice Collaborator dalam Sistem Peradilan Pidana
}

\author{
Rusli Muhammad \\ Fakultas Hukum Universitas Islam Indonesia \\ Jln. Tamansiswa No. 158 Yogyakarta \\ ruslimuhammad@uii.ac.id
}

\begin{abstract}
The first and foremost problem in this study is the setting of Whistle Blower and Justice Collaborator in Indonesia. The second is the urgency and the existence of Whistle Blowers and Justice Collaborator in the Criminal Justice System. To analyze those problems the researcher used a normative juridical research. On the basis of the study it is revealed that, first, there are some rules governing the Whistle Blower and Justice Collaborator in the Criminal Justice System, but there is no room for its setting in the Criminal Code (KUHAP). Second, the urgency and the existence of Whistle Blowers and Justice Collaborator can be found through the workings of both the Criminal Justice System in the Investigation, Prosecution, Trial and in the implementation of decisions
\end{abstract}

Keywords: Whistle blower, justice collaborator, the criminal justice system

\begin{abstract}
Abstrak
Pokok permasalahan dalam penelitian ini, pertama, pengaturan Whistle Blower dan Justice Collaborator di Indonesia. Kedua, urgensi dan eksistensi Whistle Blower dan Justice Collaborator dalam Sistem Peradilan Pidana. Metode pendekatan yang digunakan dalam penelitian ini yuridis normatif. Dari hasil penelitian ditemukan bahwa, pertama, terdapat beberapa peraturan yang mengatur mengenai Whistle Blower dan Justice Collaborator dalam Sistem Peradilan Pidana, namun dalam KUHAP belum mendapat ruang pengaturan. Kedua, urgensi dan eksistensi Whistle Blower dan Justice Collaborator dapat ditemukan melalui bekerjanya Sistem Peradilan Pidana baik dalam penyidikan, penuntutan, pemeriksaan pengadilan maupun dalam pelaksanaan putusan.
\end{abstract}

Kata Kunci: Urgensi, whistle blower, justice collaborator, sistem peradilan pidana 


\section{Pendahuluan}

Kejahatan merupakan fenomena sosial yang saat ini semakin meningkat kualitas maupun kuantitasnya. Berbagai upaya telah dilakukan untuk menekan aksi kejahatan ini. Memang sangat disadari bahwa usaha apapun yang dilakukan tidak mungkin dapat menghapus fenomena kejahatan dari muka bumi karena secara kodrati kejahatan adalah bagian dari kehidupan manusia. Jikalau ada upaya yang dilakukan, hanya terbatas sebagai upaya mengurangi angka kejahatan sehingga tidak semakin meningkat. Perkembangan masyarakat dan teknologi saat ini, diikuti pula dengan munculnya berbagai kejahatan yang semakin canggih dan terorganisir yang dapat dikategorikan sebagai extra ordinary crime. Kondisi ini kian mendorong Penegak hukum harus lebih bisa dan mampu melakukan upaya-upaya baru dalam penggalian informasi untuk dapat menangani dan membuktikan kejahatan-kejahatan nonkonvensional dengan menggunakan berbagai sarana potensial melalui suatu jaringan Sistem Peradilan Pidana.

Sistem Peradilan Pidana (disingkat SPP) adalah jaringan peradilan yang bekerja sama secara terpadu di antara bagian-bagiannya untuk mencapai tujuan tertentu baik jangka pendek maupun jangka panjang. Dalam bekerjanya didukung oleh berbagai sub-sistem antara lain Kepolisian, Kejaksaan, Pengadilan dan Lembaga Pemasyarakatan. Jaringan kerja sama antar subsistem dari Sistem Peradilan Pidana pada dasarnya telah banyak memberi perhatian dalam upaya penanggulangan kejahatan dan sudah sekian banyak kejahatan yang telah diproses melalui jaringan ini. Akan tetapi hasil yang dicapai dalam bekerjanya SPP tidak selama sesuai dengan yang diharapkan terkadang mengalami kegagalan dan bahkan tidak sejalan dengan perkembangan kejahatan itu sendiri.

Berbagai kejahatan dengan modus operandi yang semakin canggih, dilakukan perorangan maupun dengan organisasi yang sangat rapi, sementara perkembangan sistem peradilan pidana tidak seirama dengan perkembangan kejahatan itu. Sistem peradilan pidana terkadang terlambat dan tidak siap dalam mengantisipasi laju dan berkembangnya berbagai kejahatan dengan modus-modus yang berubah. Untuk itu dirasakan perlu adanya pembaharuan dalam menata sistem peradilan pidana sehingga mampu mengantisipasi berbagai modus-modus 
kejahatan yang terjadi. Keberhasilan suatu proses peradilan pidana sangat tergantung pada alat bukti yang berhasil diungkap atau dibuktikan dalam proses peradilan terutama yang berkenaan dengan saksi ${ }^{1}$.

Salah satu hal yang perlu menarik perhatian adalah munculnya Istilah Whistle Blower (WB) dan Justice Collaborator (JC). ${ }^{2}$ Istilah ini meskipun telah dikenal lama dan digunakan di beberapa negara, namun di Indonesia masih relatif baru dalam referensi hukum pidana. Meski demikian Whistle Blower (WB) dan Justice Collaborator (JC) kini semakin mendapat tempat dalam berbagai pertemuan ilmiah bahkan dalam dunia penegakan hukum mengingat keberadaannya telah memberikan nuansa baru dalam sistem peradilan pidana. Pengalaman di negaranegara yang telah mengadopsinya, keberadaan WB dan JC telah membantu sistem peradilan pidana dalam membongkar dan mengungkapan berbagai kejahatan yang terorganisir.

\section{Rumusan Masalah}

Melihat pengalaman di beberapa negara serta semakin tingginya perhatian terhadap Whistle Blower (WB) dan Justice Collaborator (JC) menjadi alasan untuk mengkaji lebih jauh masalah ini. Penelitian ini akan mengkaji dua permasalahan yakni: pertama, bagaimana pengaturan Whistle Blower (WB) dan Justice Collaborator (JC) dalam perundang-undangan Indonesia? Kedua, apa urgensi dan eksistensi Whistle Blower (WB) dan Justice Collaborator (JC) dalam sistem peradilan pidana Indonesia?

\section{Tujuan Penelitian}

Penelitian ini bertujuan untuk mengetahui, pertama, bagaimana pengaturan Whistle Blower (WB) dan Justice Collaborator (JC) dalam perundang-undangan

${ }^{1}$ Nandang Sambas dan Dian Andriasari, "Telaah Kritis terhadap Perlindungan Saksi dan Korban Kejahatan Dalam Sistem Peradilan Pidana di Indonesia”, Makalah disampaikan pada Call for Paper Simposium MAHUPIKI tgl 18-19 Maret 2013 di UNHAS Makassar.

2 Dalam SEMA MA No 4 Tahun 2011 disebutkan bahwa whistle blower adalah pihak yang mengetahui dan melaporkan tindak pidana tertentu dan bukan merupakan bagian dari pelaku kejahatan yang dilaporkan. Sedangkan Justice Collaboration merupakan salah satu pelaku tindak pidana tertentu, mengakui yang dilakukannya, bukan pelaku utama dalam kejahatan tersebut serta memberikan keterangan sebagai saksi di dalam proses peradilan. 
Indonesia. Kedua, urgensi dan eksistensi Whistle Blower (WB) dan Justice Collaborator (JC) dalam sistem peradilan pidana Indonesia.

\section{Metode Penelitian}

Penelitian ini termasuk jenis penelitian deskriptif dengan pendekatan yuridis normatif. Data yang diperlukan dalam penelitian ini lebih mengutamakan data sekunder, yakni data yang telah tersedia di dalam berbagai perpustakaan atau dalam berbagai dokumen-dokumen. Analisis terhadap data yang diperoleh dilakukan dengan cara kualitatif. Analisis kualitatif ini diperlukan untuk menjelaskan suatu rangkaian kaitan-kaitan kausal tentang fenomena tertentu, yang bersifat kompleks dan sulit diukur secara pasti. Menurut Matthew B. Miles dan A. M. Michael Huberman dalam bukunya berjudul Analisa Data Kualitatif (terjemahan) mengatakan bahwa analisa terdiri dari tiga alur kegiatan yang terjadi secara bersamaan yaitu: reduksi data, penyajian data, penarikan kesimpulan/verifikasi. ${ }^{3}$

\section{Hasil Penelitian dan Pembahasan}

\section{Pengaturan Whistle Blower (WB) dan Justice Collaborator (JC)}

Istilah Whistle Blower dalam bahasa Inggris diartikan sebagai "peniup peluit", disebut demikian karena sebagaimana halnya wasit dalam pertandingan sepak bola atau olahraga lainnya yang meniupkan peluit sebagai pengungkapan fakta akan adanya kesalahan atau terjadinya suatu pelanggaran. Saksi pelaku yang bekerja sama dikenal dengan beragam istilah, yaitu justice collaborator, cooperative, whistleblower, collaborators with justice atau peniti (Italia) ${ }^{4}$. Secara etimologi Justice collaborators berasal dari kata justice yang berarti keadilan, adil, hakim. ${ }^{5}$ Sedangkan collaborators artinya teman kerjasama atau kerjasama. ${ }^{6}$

${ }^{3}$ Matthew B. Miles dan A. Michael Huberman, Analisa Data Kualitatif, Penerbit Universitas Indonesia, Jakarta, 1992, hlm. 16.

${ }^{4}$ Abdul Haris Semendawai, "Eksistensi Justice Collaborator dalam Perkara Korupsi Catatan tentang Urgensi dan Implikasi Yuridis atas Penetapan Proses Peradilan Pidana”, Makalah disampaikan pada Stadium General Fakultas Hukum UII, Yogyakarta, 17 April 2013, hlm. 7.

5.P.M. Ranuhandoko, Terminologi Hukum Inggris Indonesia, Cet. III, Sinargrafika, Jakarta, 2003, hlm. 367. 'Jhon M. Echos dan Hasan Shaddili, Kamus Inggris-Indonesia, Gramedia, Jakarta, 2005, hlm. 124. 
Dalam perkembangan terakhir melalui Surat Edaran Mahkamah Agung RI No. 04 Tahun 2011 tentang Perlakuan bagi Pelapor Tindak Pidana (Whistle blower) dan Saksi Pelaku yang Bekerjasama (Justice Collaborator) di dalam Perkara Tindak Pidana Tertentu disebutkan sebagai pelapor tindak pidana adalah orang yang mengetahui dan melaporkan tindak pidana dan bukan bagian dari pelaku kejahatan yang dilaporkannya, sehingga seorang pelaku yang bekerjasama (Justice Collaborator) merupakan salah satu pelaku tindak pidana tertentu, mengenai kejahatan yang dilakukannya, bukan pelaku utama dalam kejahatan tersebut serta memberikan keterangan sebaga saksi di dalam proses peradilan. ${ }^{7}$

Banyak pandangan-pandangan yang sering mengungkapkan bahwa Whistle Blower merupakan saksi pelapor, atau orang yang melaporkan suatu tindak pidana korupsi atau permufakatan jahat kepada aparatur penegak hukum atau penyidik. Namun sebenarnya seseorang disebut Whistle Blower, apabila memenuhi dua kriteria yaitu:8 pertama, Whistle Blower menyampaikan atau mengungkap laporan kepada otoritas yang berwenang atau kepada media massa atau publik. Dengan mengungkapkan kepada otoritas yang berwenang atau media massa diharapkan dugaan suatu kejahatan dapat diungkap dan terbongkar. Kedua, seorang whistleblower merupakan orang 'dalam', yaitu orang yang mengungkap dugaan pelanggaran dan kejahatan yang terjadi di tempatnya bekerja atau ia berada.

Berbeda dengan Whistle Blower, Justice Collaborator adalah istilah yang digunakan terhadap seseorang yang menjadi saksi namun juga berperan bersmasama sebagai pelaku kejahatan. Di Indonesia sendiri saksi yang juga sekaligus sebagai pelaku ini di kenal dengan beberapa istilah antara lain: 1.Saksi Tersangka, 2. Saksi Pelaku yang Bekerjasama / justice Collaborator, 3. Saksi Mahkota.

Pengaturan Whistle Blower di Indonesia dapat dijumpai dalam beberapa peraturan seperti dalam PP No. 71 Tahun 2000 menyebutkan tentang pengertian Whistle Blower, yaitu orang yang memberi suatu informasi kepada penegak hukum atau komisi mengenai terjadinya suatu tindak pidana korupsi dan bukan pelapor. Dapat pula dijumpai dalam UU No. 13 Tahun 2006 tentang Lembaga Perlindungan

${ }^{7}$ Firman Wijaya, Whiste Blower dan Justice Colaborator, dalam Perspektif Hukum, Penaku, 2012, hlm. 23.

8 Abdul Haris Semendawai, dkk, Memahami Whistle Blower, Penerbit Lembaga Perlindungan Saksi dan Korban (LPSK), Jakarta, 2011, hlm. 1-2. 
Saksi dan Korban (LPSK). UU ini telah dirubah dengan UU No. 31 Tahun 2014 yakni Undang-Undang tentang Perubahan Atas Undang-Undang No. 13 Tahun 2006 tentang Perlindungan Saksi dan Korban.

Sementara itu, Justice Collaborator secara yuridis dapat ditemukan pada Surat Edaran MA (SEMA) No. 4 Tahun 2011 tentang Perlakuan bagi Whistle Blower dan Justice Collaborator. Pada SEMA tersebut, Justice Collaborator dimaknai sebagai seorang pelaku tindak pidana tertentu, tetapi bukan pelaku utama, yang mengakui perbuatannya dan bersedia menjadi saksi dalam proses peradilan. Dalam Surat Keputusan Bersama antara Lembaga Perlindungan Saksi dan Korban (LPSK), Kejaksaan Agung, Kepolisian RI, KPK dan Mahkamah Agung, Justice Collaborator adalah seorang saksi, yang juga merupakan pelaku, namun mau bekerjasama dengan penegak hukum dalam rangka membongkar suatu perkara bahkan mengembalikan aset hasil kejahatan korupsi apabila aset itu ada pada dirinya. Untuk menentukan seseorang sebagai Justice Collaborator, sesuai SEMA No. 4 Tahun 2011, ada beberapa pedoman, yaitu: yang bersangkutan merupakan salah satu pelaku tindak pidana tertentu sebagaimana dimaksud dalam SEMA ini, mengakui kejahatan yang dilakukannya, bukan pelaku utama dalam kejahatan tersebut serta memberikan keterangan sebagai saksi di dalam proses peradilan.

Pengaturan perlindungan menjadi Whistle Blower maupun Justice Collaborator memiliki perlindungan berbeda satu sama lain. Hal ini sesuai ketentuan Pasal 10 UU No. 13 Tahun 2006 tentang Perlindungan Saksi dan Korban. Pasal itu menyebutkan, Whistle Blower atau saksi pelapor tidak dapat dituntut secara hukum baik pidana maupun perdata atas laporan, kesaksian yang akan, sedang atau yang telah diberikan. Sedangkan Justice Collaborator atau saksi sekaligus tersangka dalam kasus yang sama tidak dapat dibebaskan dari tuntutan pidana apabila terbukti secara sah dan meyakinkan bersalah. Namun, kesaksiannya dapat dijadikan pertimbangan hakim dalam meringankan pidananya.

Pengaturan menjadi Whistle Blower maupun Justice Collaborator di Indonesia praktis dapat dikatakan belum ada sebelum lahirnya Undang-Undang No. 13 Tahun 2006, di dalam UU itu sendiri pasal-pasal yang mengatur serta menjabarkan tentang saksi pelaku bekerjasama dinilai sangat minim. UU tersebut juga tidak memberikan panduan yang jelas apa saja yang menjadi prasyarat untuk dapat 
menetapkan seseorang menjadi Justice Collaborator. Peran seorang pelaku yang dijadikan sebagai saksi dalam peraturan yang ada saat ini hanya dikenal dalam Pasal 10 ayat (2) Undang-Undang No. 13 Tahun 2006 seorang saksi yang juga tersangka dalam kasus yang sama tidak dapat dibebaskan dari tuntutan pidana apabila ternyata terbukti secara sah dan meyakinkan bersalah, tetapi kesaksiannya dapat dijadikan pertimbangan hakim dalam meringankan pidana yang akan dijatuhkan". Dari rumusan tersebut UU No. 13 Tahun 2006 telah memberikan payung hukum pertama mengenai pelaku yang bekerjasama yang dalam UU tersebut disebut dengan istilah "saksi yang juga tersangka".

Kendatipun Whistle Blower maupun Justice Collaborator telah diatur di dalam UU No. 13 Tahun 2006, namun setelah berjalannya waktu dan dalam pelaksanaannya, UU ini ditemukan adanya kekurangan-kekurangan dalam mengatur perlindungan terhadap saksi. Khusus pengaturan tentang peran Justice Collaborator dalam pelaksanaannya masih terdapat banyak kelemahan-kelemahan yang disebabkan berbeda-bedanya penafsiran pasal tersebut oleh masyarakat dan juga oleh penegak hukum itu sendiri. Kelemahan-kelemahan itu dapat terlihat dari: 9 a. ruang lingkup "pelaku yang bekerjasama" yang masih terbatas b. peran pelaku yang bekerjasama harus dalam pengadilan c. persyaratan yang kurang jelas d. pemberian reward yang terbatas e. tidak ada kepastian dalam pemberian reward f. pemberian perlindungan yang tidak pasti g. tidak ada standar mengenai menghitung kontribusi sebagai pelaku yang bekerjasama.

Dalam perkembangannya untuk menutup kelemahan dan kekurangan dalam Pasal 10 ayat (2) UU tersebut Mahkamah Agung memberikan panduan melalui SEMA No. 4 Tahun 2011 tentang Perlakuan bagi Pelapor Tindak Pidana (Whistle Blower ) dan Saksi Pelaku yang bekerjasama (Justice Collaborator) di dalam Perkara Tindak Pidana Tertentu, kemudian diikuti dengan Peraturan Bersama Menteri Hukum dan Hak Asasi Manusia Republik Indonesia, Jaksa Agung Republik Indonesia, Kepala Kepolisian Negara Republik Indonesia, Komisi Pemberantasan Korupsi Republik Indonesia, Ketua Lembaga Perlindungan Saksi

9Supriyadi Widodo Eddyono, "Prospek Penggunaan Pelaku yang Bekerjasama di Indonesia" Jurnal LPSK Volume ke 1, No. 1 Tahun 2011, hlm. 104-108. 
dan Korban Republik Indonesia Tentang Perlindungan Bagi Pelapor, Saksi Pelapor dan Saksi Pelaku yang Bekerjasama. Namun peraturan-peraturan tersebut masih juga memiliki kelemahan yaitu sifat dari peraturan itu sendiri yang berupa surat edaran yang dapat diartikan dapat diikuti atau tidak diikuti tergantung dari subyektifitas dari penegak hukum itu sendiri.

Adanya kelemahan-kelemahan dan kekurangan tersebut khususnya yang terdapat dalam UU No. 13 Tahun 2006, maka layak jika kemudian UU ini diubah dengan dikeluarkannya UU No. 31 Tahun 2014 tentang Perubahan Atas UndangUndang No. 13 Tahun 2006 tentang Perlindungan Saksi dan Korban. UU No. 31 Tahun 2014 menentukan definisi saksi dan saksi pelaku sebagaimana disebutkan dalam Pasal 1 yakni : 1) Saksi adalah orang yang dapat memberikan keterangan guna kepentingan penyelidikan, penyidikan, penuntutan, dan pemeriksaan di sidang pengadilan tentang suatu tindak pidana yang ia dengar sendiri, ia lihat sendiri, dan/atau ia alami sendiri. 2) disebutkan Saksi Pelaku adalah tersangka terdakwa, atau terpidana yang bekerja sama dengan penegak hukum untuk mengungkap suatu tindak dalam kasus yang sama. ${ }^{10}$ Untuk memberikan jaminan perlindungan hukum yang lebih baik kepada Whistle Blower maupun Justice Collaborator maka dalam Pasal 10 UU 31 Tahun 2014 menyebutkan bahwa : (1) Saksi, Korban, Saksi Pelaku, dan/atau Pelapor tidak dapat dituntut secara hukum, baik pidana maupun perdata atas kesaksian dan/atau laporan yang akan, sedang, atau telah diberikannya kecuali kesaksian atau laporan tersebut diberikan tidak dengan iktikad baik; (2) Dalam hal terdapat tuntutan hukum terhadap Saksi, Korban, Saksi Pelaku, dan/atau Pelapor atas kesaksian dan/atau laporan yang akan, sedang, atau telah diberikan, tuntutan hukum tersebut wajib ditunda hingga kasus yang ia laporkan atau ia berikan kesaksian telah diputus oleh pengadilan dan memperoleh kekuatan hukum tetap. Kemudian diantara Pasal 10 dan Pasal 11 disisipkan 1 (satu) pasal, yakni Pasal 10A yang berbunyi sebagai berikut: Pasal 10A ayat (1) Saksi Pelaku dapat diberikan penanganan secara khusus dalam proses pemeriksaan dan penghargaan atas kesaksian yang diberikan. (2) Penanganan secara khusus sebagaimana dimaksud pada ayat (1) berupa: a. pemisahan tempat penahanan

${ }^{10}$ Sumber : http://www.hukumonline.com 
atau tempat menjalani pidana antara Saksi Pelaku dengan tersangka, terdakwa, dan/atau narapidana yang diungkap tindak pidananya; b. pemisahan pemberkasan antara berkas Saksi Pelaku dengan berkas tersangka dan terdakwa dalam proses penyidikan, dan penuntutan atas tindak pidana yang diungkapkannya; dan/atau c. memberikan kesaksian di depan persidangan tanpa berhadapan langsung dengan terdakwa yang diungkap tindak pidananya. (3) Penghargaanatas kesaksian sebagaimana dimaksud pada ayat (1) berupa: a. keringanan penjatuhan pidana; atau b. pembebasan bersyarat, remisi tambahan, dan hak narapidana lain sesuai dengan ketentuan peraturan perundang-undangan bagi Saksi Pelaku yang berstatus narapidana. (4) Untuk memperoleh penghargaan berupa keringanan penjatuhan pidana sebagaimana dimaksud pada ayat (3) huruf a, LPSK memberikan rekomendasi secara tertulis kepada penuntut umum untuk dimuat dalam tuntutannya kepada hakim; (5) Untuk memperoleh penghargaan berupa pembebasan bersyarat, remisi tambahan, dan hak narapidana lain sebagaimana dimaksud pada ayat (3) huruf b, LPSK memberikan rekomendasi secara tertulis kepada menteri yang menyelenggarakan urusan pemerintahan di bidang hukum.

Adanya Pasal 10A UU No. 31 Tahun 2014 tersebut semakin mengukuhkan pemberian hak perlindungan kepada Whistle Blower dan Justice Collaborator, yakni: pertama, perlindungan fisik dan psikis. Kedua, perlindungan hukum. Ketiga, penanganan secara khusus, dan keempat, memperoleh penghargaan.

Untuk penanganan secara khusus, seperti tersebut dalam Pasal $10 \mathrm{~A}$, terdapat beberapa hak yang bisa diperoleh Whistle Blower atau Justice Collaborator tersebut, yaitu dipisahnya tempat penahanan dari tersangka atau terdakwa lain dari kejahatan yang diungkap, pemberkasan perkara dilakukan secara terpisah dengan tersangka atau terdakwa lain dalam perkara yang dilaporkan. Kemudian, dapat memperoleh penundaan penuntutan atas dirinya, memperoleh penundaan proses hukum seperti penyidikan dan penuntutan yang mungkin timbul karena informasi, laporan dan atau kesaksian yang diberikannya. Serta bisa memberikan kesaksian di depan persidangan tanpa berhadapan langsung dengan terdakwa yang diungkap tindak pidananya.

Selain penanganan secara khusus, saksi sekaligus pelaku tindak pidana tersebut bisa memperoleh penghargaan berupa keringanan tuntutan hukuman, 
termasuk tuntutan hukuman percobaan, serta memperoleh pembebasan bersyarat, pemberian remisi dan hak-hak narapidana lain sesuai peraturan perundangundangan yang berlaku apabila saksi pelaku yang bekerjasama adalah seorang narapidana. Semua hak ini bisa diperoleh oleh Whistle Blower atau Justice Collaborator dengan persetujuan atau mendapat rekomendasi dari LPSK.

Kitab Undang-Undang Hukum Acara Pidana (KUHAP) yang saat ini masih berlaku, dalam kenyataannya belum memberikan ruang bagi pelaku yang dijadikan saksi, belum adanya regulasi/pengaturan serta pelaksanaan pemberian reward dan perlindungan yang dapat diberikan kepada saksi pelaku bekerjasama, peraturan yang ada saat ini dirasa masih belum cukup banyak mengakomodir akan kebutuhan penegak hukum dan instansi/lembaga lain yang berperan dalam pelaksanaan penerapan reward dan perlindungan bagi saksi pelaku yang bekerjasama.

Memperhatikan kondisi KUHAP sebagaimana diuraikan di atas, maka sangat mendesak untuk segera dilakukan perubahan-perubahan serta penambahanpenambahan untuk dapat dan mampu mengakomodir perkembangan hukum pidana, tidak terbatas dengan pembahasan Justice Collaborator saja, namun turunannya termasuk mekanisme reward, perlindungan dari istilah tersebut dengan tujuan dapat memberikan kepastian, kemanfaatan serta keadilan bagi semua pihak aturan- aturan yang dibutuhkan adalah yang dapat dijadikan panduan bagi penegak hukum agar tidak bertentangan dengan konsep penyelenggaraan peradilan yang baik dan tidak menyalahi prinsip-prinsip hak asasi manusia.

Rancangan Undang-Undang KUHAP yang sekarang sudah ditangan DPR, adalah harapan baru untuk dapat mengakomodir berbagai pemikiran dan perkembangan peraturan hukum yang ada dan sekaligus menjadi payung dan panduan bagi penegak hukum, khususnya dalam mengungkap berbagai kejahatan yang meresahkan masyarakat bangsa dan negara.

\section{Urgensi dan Eksistensi Whistle Blower (WB) dan Justice Collaborator (JC)}

Pembahasan pada sub judul ini adalah menyangkut tema sentral dari penelitian ini yakni urgensi dan eksistensi Whistle Blower (WB) dan Justice Collaborator (JC) dalam sistem peradilan pidana. Pembahasan terhadap tema ini 
akan menggunakan bekerjanya sistem peradilan pidana dalam melihat urgensi dan eksistensi JB dan JC dalam sistem peradilan pidana.

Sebagaimana telah diketahui bahwa bekerjanya sistem peradilan pidana melalui beberapa tahapan yakni tahapan Penyelidikan, Penyidikan, Penuntutan, Pemeriksaan Pengadilan hingga Pelaksanaan putusan. Untuk mengetahu urgensi dan eksistensi WB dan JC dalam sistem peradilan pidana, berikut ini akan diuraikan berdasarkan tahapan-tahapan bekerjanya sistem peradilan pidana tersebut.

\section{Pada tahap Penyelidikan dan Penyidikan}

Tahap penyelidikan dan penyidikan adalah awal dari proses pemeriksasan perkara pidana, keberhasilan tahap ini menentukan tahap-tahap selanjutnya. Tahap ini, yang terpenting adalah mencari dan menemukan suatu fakta kebenaran materiil setidak-tidaknya mendekati kebenaran materiil berkaitan dengan peristiwa yang terjadi baik sebelum, sedang maupun sesudah perbuatan pidana dilakukan, termasuk menemukan siapa pelaku suatu kejahatan.

Berbagai langkah yang dapat dilakukan untuk menemukan fakta-fakta suatu kejahatan misalnya dalam tindakan penyelidikan yaitu: menerima laporan, mencari keterangan dan barang bukti, menyuruh berhenti orang yang dicurigai dan menanyakan serta memeriksa tanda pengenal diri. Sementara dalam penyidikan, penyidik dapat melakukan tindakan pertama di tempat kejadian, pemanggilan dan pemeriksaan tersangka dan saksi serta melakukan upaya paksa yang diperlukan. Meskipun berbagai langkah dapat dilakukan namun terkadang dalam mengungkap suatu kejahatan lebih-lebih untuk menemukan dan mendapatkan fakta yang mengandung kebenaran terkadang mengalami kesulitan terutama jika berhadapan dengan kejahatan yang dilakukan dengan rapi dan terorganisir.

Mencari dan menemukan fakta kebenaran untuk kasus-kasus yang ringan tidaklah sulit namun dalam berbagai kasus yang berat yang pelakunya dari kelompok intelektual atau mereka yang berdasi,pasti sangat sulit membongkarnya sehingga dalam mencari dan menemukan fakta-faktanya pun tidak mudah diperoleh, pengungkapan dan penanganan kasusnya umumnya lamban, tertunda- 
tunda bahkan dapat lenyap tertelan waktu. Pada kondisi yang demikian menjadi sangat berarti atau urgensinya White Blower dan Justice Collaborator dalam penyelidikan dan penyidikan.

Hadirnya White Blower dan Justice Collaborator dalam proses ini, Penyelidik dan Penyidik dengan sendirinya dapat terbantu dalam mengungkap dan menemukan fakta-fakta materiil yang semula tertutup menjadi terang menderang. Eksistensi White Blower dan Justice Collaborator dalam tahapan ini adalah membantu kepolisian dalam mencari dan menemukan fakta-fakta yang berhubungan dengan kejahatan baik sebelum kejahatan dilakukan maupun sesudah kejahatan itu dilakukan. Sejalan dengan itu Ramli Atmasasmita mengatakan:

"Tujuan dari keberadaan whistle blower adalah memudahkan tugas penyidikan sehingga suatu perkara dapat diungkap tuntas sampai kepada intellectual-dader dan pimpinan organisasi kejahatan. Sementara justice collaboration adalah setiap tersangka yang terlibat organisasi kejahatan dan telah melakukan suatu tindak pidana baik atas inisiatif sendiri maupun atas permintaan aparatur hukum untuk kerja sama dengan penegak hukum menemukan alat-alat bukti dan barang bukti sehingga penyidikan dan penuntutan dapat berjalan efektif."11

Salah satu contoh kasus yang pernah terjadi adalah laporan dari Vincentius, yang membeberkan kejahatan pajak yang diduga dilakukan oleh Asian Agri Group yang membuat negara rugi sekitar Rp. 1.300.000.000.000,00. Vincent menyerahkan dokumen internal Asian Agri Group kepada Komisi Pemberantasan Korupsi, yang berisi penggelapan pajak oleh Asian Agri selama 2002-2005. Komisi Pemberantasan Korupsi kemudian melimpahkan dokumen tersebut ke Direktorat Jendral Pajak Departemen Keuangan. Berdasarkan laporan tersebut Direktorat Pajak melakukan penyelidikan terhadap Asian Agri serta melakukan penyitaan terhadap lebih dari seribu kardus dokumen dan sebuah ruko. Direktorat Pajak kemudian menetapkan dua belas tersangka dalam kasus ini. ${ }^{12}$ Dengan laporan Vincent berupa keterangan, informasi dan bukti-bukti dapat dengan jelas menunjukkan dengan jelas dan detail dugaan pelanggaran pajak sehingga BAP yang dibuat oleh Penyidik semakin lengkap dan siap diserahkan ke Kejaksaan.

11 Ramli Atmasasmita" Justice Collaborator, Mungkinkah? ”, SINDO, 24 Mei 2012.

12 Suhud, Chandra A, dkk, Potret Saksi dan Korban Dalam Media Massa, Penerbit Lembaga Perlindungan Saksi dan Korban (LPSK) 2012, hlm. 2-3. 


\section{Pada Tahap Penuntutan}

Tahap penuntutan ini adalah tahap di wilayah institusi kejaksaan, dengan memberi kewenangan penuh kepada jaksa penunutut umum untuk melakukan penuntutan itu. Penuntutan dapat dilakukan Jika Jaksa Penuntut Umum berpendapat bahwa BAP yang disampaikan oleh Penyidik telah lengkap.

Penuntutan suatu perkara dapat dilakukan dengan berbagai cara, ${ }^{13}$ yakni: Pertama, dengan cara biasa.Yaitu dilakukan jika suatu perkara itu termasuk perkara biasa yang ancaman pidananya di atas satu tahun. Penuntutan perkara dengan cara biasa ditandai pula dengan adanya berkas perkara yang lengkap dan rumit, yang memuat berbagai berita acara yang telah disusun oleh penyidik. Ciri utama dari penuntutan ini, yakni selalu disertai dengan surat dakwaan yang disusun secara cermat dan lengkap oleh jaksa penuntut umum dan penuntut umum yang menyerahkan sendiri berkas perkara tersebut dan harus hadir pula di sidang pengadilan.

Kedua, selain penuntutan dengan cara biasa, penuntutan dapat pula dilakukan dengan cara singkat dan penuntutan dengan cara cepat, perbedaannya terletak pada ada tidaknya surat dakwaan dan jenis pidana serta kualitas kejahatan dilakukan. Tahap penuntutan ini bukan suatu persoalan, masalahnya adalah pada kelengkapan dalam penuntutan yakni telah siapnya surat dakwaan karena setiap penuntutan dengan cara biasa harus disertai surat dakwaan.

Surat dakwaan disusun berdasarkan BAP yang diajukan oleh Penyidik. Kesempurnaan dan kelengkapan dalam BAP akan berakibat kelengkapan dan kesempurnaan pula dalam menyusun dakwaan. Meskipun demikian Penuntut Umum tetap dituntut agar cermat dan teliti dalam menyusun dakwaannya jangan sampai terjadi kesalahan misalnya dalam merumuskan tindak pidana dan ancaman pasal-pasalnya tidak sesuai dengan fakta-fakta perbuatan atau peristiwa-peristiwa yang sesungguhnya terjadi.

Untuk menghindari kesalahan dalam menyusun dakwaan dan agar ditemukan ketepatan baik dalam menenetukan perbuatan pidana dan pasal-pasal tuntutannya serta ketepatan terdakwanya dibutuhkan pula informasi yang tepat dari sumber yang

13 Rusli Muhammad, Sistem Peradilan Pidana, UII Press, Cetakan Pertama, Yogyakarta, 2011, hlm. 66-67. 
terpercaya dan bertanggung jawab. Dalam hal ini sumber informasi dari Whistle Blower dan Justice Collaborator adalah menjadi hal yang utama dan sangat diperlukan. Oleh karena itu urgensi Whistle Blower (WB) dan Justice Collaborator (JC) dalam tahap penuntutan adalah menghindari adanya kesalahan dan ketidaktepatan dalam menyusun surat dakwaan, menghindari adanya ketidaksesuaian antara uiraian perbuatan dengan pasal-pasal yang didakwakan dan menjadi dasar penuntutan serta ketepatan dalam mengajukan terdakwa. Dengan demikian dapat pula diketahui bahwa eksistensi Whistle Blower dan Justice Collaborator dalam tahap penuntutan adalah sebagai sumber informasi yang terpercaya yang diharapkan dapat memberikan keterangan yang sebenarnya sehingga penuntutan dengan surat dakwaan yang dibuat memiliki kekuatan hukum dan menjadi dasar pemeriksaan yang kuat pula di sidang pengadilan.

\section{Pada Tahap Pemeriksaan Pengadilan}

Tahap pemeriksaan di sidang pengadilan diawali dengan penetapan majelis hakim, selanjutnya ditetapkan hari sidang. Setelah tiba hari persidangan, hakim menyatakan sidang dibuka dan terbuka untuk umum, kecuali dalam perkara tertentu di mana sidang harus dinyatakan tertutup untuk umum. Setelah itu dilakukan pemeriksaan identitas terdakwa, kemudian diteruskan dengan pembacaan surat dakwaan oleh jaksa penuntut umum. Terkadang terdapat eksepsi dari terdakwa, jika tidak maka diteruskan dengan pemeriksaan atau dikenal dengan pembuktian. Bagian ini yang paling penting dari tiap tahapan atau proses perkara pidana, khususnya bagi terdakwa karena dari hasil pemeriksaan inilah tergantung apakah terdakwa akan dinyatakan terbukti atau tidak, bersalah atau tidak sehingga akan mewarnai putusan hakim.

Pada tahap persidangan ini dengan kendali Ketua Hakim majelis, masingmasing pihak berupaya menyampaikan dan mengedepankan kepentingannya. Jaksa Penuntut Umum berupaya agar dakwaannya dinyatakan terbukti sementara terdakwa atau penasihat hukumnya berupaya membela atau membebaskan diri dari dakwaan jaksa. Pembuktian yang dilakukan adalah pemeriksaan terhadap alat-alat bukti dan barang bukti yang didahului dengan memeriksa saksi-saksi baik yang diajukan penuntut umum maupun terdakwa, pemeriksaan barang bukti 
bersamaan dengan pemeriksaan aksi. Jika diminta diteruskan dengan mendengar keterangan ahli. Pembuktian diakhiri dengan pemeriksaan terhadap terdakwa.

Proses pembuktian akan berjalan lancar dan tidak akan banyak masalah jika menghadapi perkara-perkara yang nilai komersialnya tidak tinggi dan tidak berdampak luas, pembuktiannya ringan dan mudah diselesaikan tampa memakan waktu yang lama. Namun, jika berhadapan dengan perkara yang bernilai tinggi, berdampak luas, merugikan negara dan terorganisir, umumnya proses pembuktiannya terkadang menimbulkan persoalan, seperti proses pembuktian yang sulit, memakan waktu yang panjang, bahkan terkadang terjadi keterangan saksi berubah-ubah atau bertentangan satu sama lainnya sehingga tidak memperlihatkan kesesuaian antara keterangan saksi yang satu dengan keterangan saksi yang lain, atau tidak ada kesesuaian antara keterangan saksi dengan alat bukti atau barang bukti lainnya. Hal yang demikian menjadi petaka bagi Jaksa Penuntut Umum sehingga kemungkinan akan menghadirkan lagi tambahan bukti lainnya Demikian pula bagi hakim menjadi tidak mudah dalam menentukan putusan yang dijatuhkan.

Kondisi pembuktian yang demikian memerlukan terobosan dan inovasi baru dalam sistem peradilan pidana, tanpa perubahan, SPP akan tertinggal dan akan tetap menghasilkan putusan-putusan hukum tanpa ada daya preventif dalam menghadapi berbagai modus kejahatan. Kehadiran dan diakomodirnya Whistle Blower(WB) dan Justice Collaborator (JC) dalam sistem peradilan pidana sangat membantu dalam pengungakapan kejahatan terutama dalam proses pembuktian dan pengambilan putusan oleh Hakim. Whsitle Blower (WB) dan Justice Collaborator (JC) akan menjadi saksi kunci dalam persidangan dan dengan keterangan yang disampaikan didukung oleh saksi lain serta alat-alat bukti lain akan memberikan dan menumbuhkan keyakinan bagi hakim dalam menjatuhkan putusannya.

Justice Collaborator (JC) memiliki peran penting dalam hal membantu membongkar dan mengungkapkan ksus-kasus yang tergolong dalam tindak pidana yang terorganisir. Dimana dalam praktek peradilan aparat hukum seringkali menemukan berbagai kendala yuridis dan non yuridis untuk mengungkap tuntas dan menemukan kejelasan suatu tindak pidana terutama dalam menghadirkan saksi-saksi kunci dalam proses hukum sejak penyidikan 
sampai proses pengadilan. ${ }^{14}$ Sejalan dengan itu, Maharani Siti Shopiah dalam keterangan persnya menyebutkan, peran seorang Justice Collaborator (JC) dalam mengungkap suatu kejahatan terorganisir sangat besar dan informasinya sangat penting untuk membantu aparat penegak hukum dalam mengungkap jaringan kejahatan yang selama ini tertutup sangat rapi. ${ }^{15}$

Eksistensi Whistle Blower (WB) dan Justice Collaborator (JC) dalam setiap persidangan perkara pidana sangat penting karena selain berjasa dalam menjernihkan permasalahan dalam persidangan keterangan mereka kerap pula mempengaruhi dan menentukan kecenderungan keputusan hakim. Seorang Whsitle Blower (WB) dan Justice Collaborator (JC) ketika dihadirkan sebagai saksi di sidang pengadilan, keterangannya sudah pasti akan mengikat hakim dan mempunyai kekuatan hukum pembuktian sehingga akan menentukan arah kemana keputusan hakim akan dijatuhkan . Hal ini memberi efek kepada setiap keterangan saksi selalu mendapat perhatian yang sangat besar baik oleh pelaku hukum yang terlibat didalam persidangan maupun oleh masyarakat pemerhati hukum. ${ }^{16}$

Whitsle Blower (WB) dan Justice Collaborator (JC) menjadi kebutuhan dalam persidangan, karena mereka dapat memberikan informasi atau keterangan yang mereka alami sendiri, mereka lihat sendiri bukan keterangan yang dibuat-buat atau direkayasa. Informasi yang disampaiakn merupakan suatu peristiwa faktual atau benar-benar diketahui, bukan informasi yang bohong atau fitnah. Dalam kasus korupsi Whistle Blower (WB) dan Justice Collaborator (JC) berperan untuk memudahkan pengungkapan tindak pidana korupsi, karena mereka sendiri tidak lain adalah orang dalam di dalam institusi di mana ditengarai telah terjadi praktik korupsi.

Selain memberikan informasi atau keterangan yang akurat baik ditingkat penyidikan, penuntutan maupun dalam persidangan, Whistle Blower (WB) dan Justice Collaborator, (JC) berperan pula dalam mengungkap pelaku-pelaku lainnya yang memiliki peran yang lebih besar atau pengembalian aset-aset hasil dari

${ }^{14}$ Firman Wijaya., Op.Cit., hlm. 19.

15 Pernyataan Maharani Siti Shopiah, dalam Harian Tribun Nasional, Minggu, 30 Juni 2013, hlm.2.

${ }^{16}$ Tim Fakultas Hukum Universitas Bhayangkara Jakarta. "Mewujudkan Perlindungan Saksi dan Korban Dalam Sistem Peradilan Pidaana di Indonesia”. Penerbit : Lembaga Perlindungan Saksi dan Korban 2011, hlm. 141. 
tindak pidana korupsi atau dari kejahatan perpajakan. Pengalaman membuktikan dua kasus perpajakan besar yang mendapat sorotan akibat peran Whistle Blower (WB) dan Justice Collaborator (JC) adalah kasus penyimpangan pajak yang melibatkan mantan pegawai Dirjen, Gayus Tambunan dan kasus penggelapan pajak Asian Agri Group sebagaimana tersebut di atas.

\section{Pada Tahap Pelaksanaan Putusan}

Tahap pelaksanaan putusan adalah tahap yang paling akhir dalam sistem peradilan pidana yang dilakukan oleh sub-sistem Pemasyarakatan. Harapan dan tujuan dari sub sistem ini, berupa aspek pembinaan dari penghuni Lembaga Pemasyarakatan (LAPAS) yang disebut narapidana (NAPI). Tata cara pelaksanaannya pembinaan telah diatur dengan UU No. 12 Tahun 1995 tentang Lembaga Pemasyarakatan.

Seperti kita ketahui, bahwa pada tahap purna ajudikasi, status seorang pelaku tindak pidana sudah jelas dinyatakan sebagai orang yang bersalah menurut hukum. Dalam posisi yang demikian ini, sebagai orang yang telah dianggap melanggar dan menyimpang dari norma-norma masyarakat, ia harus dibina agar dapat kembali menjadi warga masyarakat yang taat hukum. Pembinaan merupakan kegiatan yang bersifat kontinyu dan intensif. Melalui pembinaan, terpidana diarahkan agar menyadari kesalahannya, memperbaiki diri dan tidak melakukan tindak pidana lagi. Satu hal yang sangat penting dalam melakukan pembinaan adalah pembinaan tidak dimaksudkan untuk menderitakan, dan terpidana tetap diakui hak-hak asasinya sebagai manusia. Dengan kata lain, terpidana harus tetap memperoleh keadilan yang sesuai dengan kedudukannya sebagai seorang yang telah dinyatakan bersalah menurut hukum.

Justice Collaborator (JC) yang telah mendapat pidana dan sedang menjalani pidananya, sepertinya pada tahap ini, urgensi dan eksistensinya tidak ditemukan dan diperlukan lagi mengingat di dalam lembaga pemasyarakatan seolah-olah dianggap tidak ada dan tidak dikenal lagi istilah Justice Collaboration (JC) dan tidak pula diperlukan lagi perlindungan bagi mereka. Namun, pada kenyataannya tidak demikian, karena meskipun para Justice Collaboration (JC) ini telah berada pada tahap pelaksanaan putusan, tidak berarti kehilangan urgen dan eksistensinya 
dalam peradilan pidana khususnya pada lembaga pemasyarakatan. Masih ingat kasus korupsi pengadaan alat simulator di Korp Lalu Lintas yang terungkap atas informasi yang disampaikan oleh Sukotjo dari balik tembok penjara. Atas laporan Sokotjo tersebut KPK menetapkan sejumlah tersangka salah satunya adalah Irjen Djoko Susilo yang saat itu menjabat sebagai Gubernur Akademi Kepolisian.

\section{Penutup}

Dari keseluruhan uraian tersebut di atas dapat disimpulkan: pertama, sejak diundangkannya UU No. 13 Tahun 2006 adalah awal diaturnya Whistle Blowers dan Justice Collaborator, kemudian UU ini dilengkapi dengan SEMA No. 04 Tahun 2011 dan akhirnya diubah dengan UU No. 31 Tahun 2014. Meskipun telah mendapat mengaturan dalam perundang-undangan namun KUHAP sebagai payung hukum dalam Sistem Peradilan Pidana belum memberi ruang pengaturan Whistle Blower dan Justice Collaborator. Kedua, berkaitan dengan urgensi dan eksistensi Whistle Blower dalam sistem peradilan pidana: (i) pada tahap penyelidikan dan penyidikan, Whistle Blower dan Justice Collaborator dapat membantu dalam mengungkap dan menemukan fakta-fakta materiil tentang suatu kejahatan yang semula tertutup menjadi terang sekaligus menemukan pelaku dan pelaku lainnya; (ii) pada tahap penuntutan, sebagai sumber informasi yang terpercaya diharapkan dapat memberikan keterangan yang sebenarnya sehingga penuntutan dengan surat dakwaan yang dibuat memiliki kekuatan hukum dan menjadi dasar pemeriksaan yang kuat pula di sidang pengadilan; (iii) pada tahap pemeriksaan di sidang pengadilan dapat membantu dalam pengungakapan kejahatan terutama dalam proses pembuktian. (iv) pada tahap pelaksanaan putusan, dapat membantu dalam mengungkap kejahatan dan pelaku lainnya serta pengembalian aset dari suatu kejahatan.

Adapun saran yang dapat diajukan adalah sebagai berikut: pertama, karena KUHAP belum mengatur Whistle Blower dan Justice Collaborator, maka diharapkan dalam RUU KUHAP dapat memberikan ruang sehingga menjadi pegangan bagi penegak hukum dalam memberi jaminan perlindungan bagi Whistle Blower dan Justice Collaborator dan sekaligus menjadi pegangan dalam mengungkap kejahatan. 
Kedua, dengan adanya urgensi dan eksistensi Whistle Blower dan Justice Collaborator dalam sistem peradilan pidana maka disarankan, ke depan dalam upaya pembaharuan sistem peradilan pidana perlu dipertimbangkan untuk mengatur lebih jauh dan rinci tentang eksistensi Whistle Blower dan Justice Collaborator terutama perlindungan dan penghargaan yang dapat diberikan mengingat keterangan meereka sangat berarti.

\section{Daftar Pustaka}

Atmasasmita, Ramli, " Justice Collaborator, Mungkinkah?", SINDO, 24 Mei 2012.

Echos, Jhon M., dan Hasan Shaddili, Kamus Inggris-Indonesia, Gramedia, Jakarta, 2005.

Miles, Matthew B. dan A. Michael Huberman, "Analisa Data Kualitatif", Penerbit Universitas Indonesia, Jakarta, 1992,

Muhammad, Rusli, Sistem Peradilan Pidana, Cetakan Pertama, UII Press, Yogyakarta, 2011.

Ranuhandoko, I.P.M., Terminologi Hukum Inggris Indonesia, Cet. III, Sinar Grafika, Jakarta, 2003.

Sambas, Nandang dan Dian Andriasari, Telaah Kritis Terhadap Perlindungan Saksi dan Korban Kejahatan dalam Sistem Peradilan Pidana di Indonesia, Makalah disampaikan pada Call for Paper Simposium MAHUPIKI tanggal 18-19 Maret 2013.

Semendawai, Abdul Haris, dkk, Memahami Whistleblower, Penerbit Lembaga Perlindungan Saksi dan Korban (LPSK), Jakarta, 2011.

Semendawai, Abdul Haris, Eksistensi Justice Collaborator dalam Perkara Korupsi Catatan tentang Urgensi dan Implikasi Yuridis atas Penetapan Proses Peradilan Pidana, Makalah disampaikan pada Stadium General Fakultas Hukum UII, Yogyakarta, 17 April 2013.

Shopiah, Maharani Siti, Harian Tribun Nasional, Minggu, 30 Juni 2013.

Suhud, Chandra A., dkk, Potret Saksi dan Korban Dalam Media Massa, Penerbit Lembaga Perlindungan Saksi dan Korban (LPSK) Tahun 2011.

Supriyadi Widodo Eddyono, "Prospek Penggunaan "Pelaku yang Bekerjasama" di Indonesia", Jurnal LPSK Volume ke 1. No1 Tahun 2011.

Tim Fakultas Hukum Universitas Bhayangkara Jakarta. “Mewujudkan Perlindungan Saksi dan Korban Dalam Sistem Peradilan Pidaana di Indonesia". Penerbit : Lembaga Perlindungan Sakksi Dan Korban 2011. 
Wijaya, Firman, Whiste Blower dan Justice Colaborator, dalam Perspektif Hukum, Penaku, 2012.

UU No. 12 Tahun 1995 tentang Lembaga Pemasyarakatan.

UU No 13 Tahun 2006 Tentang Lembaga Perlindungan Saksi dan Korban (LPSK).

Surat Edaran Mahkamah Agung RI No. 04 Tahun 2011 tentang Perlakuan Bagi Pelapor Tindak Pidana dan Saksi Pelaku yang Bekerjasama 